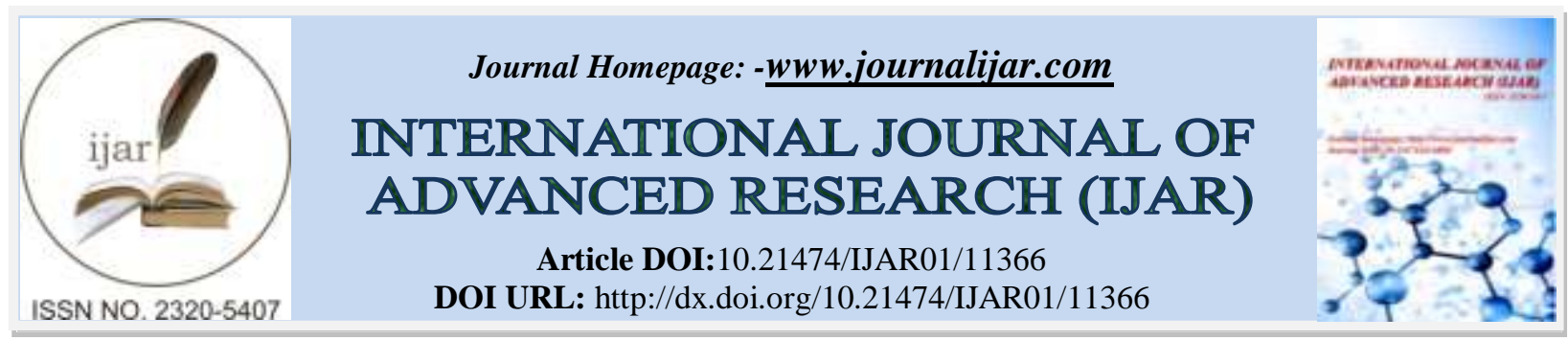

RESEARCH ARTICLE

\title{
A STUDY ON THE ASSESSMENT OF THE TREND, COMPOSITION AND REASONS OF INCREASE IN FERTILISER SUBSIDY
}

Preeti Yadav and Prof. (Dr.) Jayrajsinh D. Jadeja

\section{Manuscript Info}

Manuscript History

Received: 20 May 2020

Final Accepted: 24 June 2020

Published: July 2020

Key words:-

Fertiliser Subsidy, Trend, India's Position

\begin{abstract}
In the Indian context budgetary subsidy has seen a huge influx over the recent years. In the current paper this trend will be further analyzed and the reasons of the increase of the fertilizer subsidy will be discussed. The investigations into the field have suggested that the subsidies of the fertilizers have grown at a sharp rate till the year 2008. Soon after this point the rate has declined at a considerable rate. Nevertheless it is still one of the major parts of the subsidies that are provided in India. The paper has suggested that a national Policy for targeting subsidies must be formed. At the end of the thesis certain recommendations have been made so that the fiscal discipline can be benefited. The subsidies must be rationalized and the subsidies must be provided to the financially weaker segments of the society. This can be done by providing the subsidies directly to the bank accounts of these people under the guidelines of the Direct Benefit Scheme (DBS).
\end{abstract}

Copy Right, IJAR, 2020,. All rights reserved.

\section{Introduction:-}

The topic of subsidy management has been a hotly debated issue in India. The debate mainly concentrates in the efficiency matters versus equity. The neo-liberal philosophy has opined that subsidies happen to be unsustainable from an economic point of view and it is rather inefficient. The socialist school argued that subsidies play a rather important role in the maintenance of the social equity. The government however faces the dilemma of selecting between economic efficiency and social equity. It is important that an empirical analysis is done on the subsidy composition, the pattern of their growth and their effect on fiscal deficit. In context of Indian fertilizers, food and fuel subsidies which are also referred to as the explicit subsidies make up about $95 \%$ of the entire lot of subsidies provided. In this entire gamut the fertilizer subsidy occupies the highest portion that contributes to the fiscal deficit of the nation. Since the National Food Security Act that was enacted in the year 2013 food subsidy has increased in a huge way and occupies about $60 \%$ of the entire gamut of explicit subsidy.

India happens to be the second largest consumer of fertilizer on a global scale is second only to China. Even though we are the third biggest makers of fertilizer but as compared to our demand for fertilizer our produce always falls short and hence imports becomes imperative. Nearly $80 \%$ of the Indian need of Urea is satiated by its own produce. Even then India happens to be much dependent on the imports of potassic and phosphatic fertilizers either as raw materials or as finished items. The entire need for potash and $90 \%$ of its phosphatic needs and $20 \%$ of its urea is satiated through the imports it has [1].

\section{Objective of the Study:-}

The objective of the paper is, to study the trend, pattern and reform issues pertaining to fertiliser subsidy in India. 


\section{Fertilizer Subsidies in India:}

India has a supply of fertile land which is fairly inelastic, used for cultivation [2]. In the view of this phenomenon the Indian system of agriculture is bound to use strategies to maintain and also improve the rate of production of food. In this context high yielding variety of seeds are used, better measures of irrigation are put to use and a higher application of fertilizers are done in India so that the country can maintain a self-sufficiency in the domain of production of food grains. The use of better fertilizers is often held responsible for an increase of about 50 to $60 \%$ in its food grain production [3]. Introducing subsidies for chemical fertilizers was a rather important step in the aim of making them available at an affordable rate for the Indian farmers [3]. This was a step that made a huge contribution in increasing the food production of the nation. The practice of giving fertilizer subsidies is in vogue in a number of countries across the world so that the market imperfections can be controlled, attain equitable distribution and also improve the production of food grains. In many countries this practice becomes a patronage on the part of the political parties and is very challenging when intended to be replaced. The effect of fertilizer subsidies can be seen in the overall use of the fertilizers and also the enhancement in the production of the food items. In the year 1950 51 if the consumption of fertilizer was about 65.6 thousand tones then in $2009-10$ it increased to 26,400 thousand tones. The food production also shot up from 51.9 million tonnes to 218.2 million tonnes during the same span of period.

However there are enough evidences in the literature that indicates at an irresponsible and overt use of the subsidized fertilizers. As a result of the same we see that the crop response to the chemical fertilizers did fall to a considerable degree [4]. An overt use of the fertilizers also did have rather adverse effects on the nutrient quotient of the social and affected the environment in an adverse manner in the long run [5]. The relentless practice of providing subsidies on chemical fertilizers also sums up a major economic burden. This is a growing cause of concern [6]. The rates at which the subsidies grew were really alarming. What were about 60 crores in $1976-72,000$ crores in $2010-$ 11. There is also a school of opinion holders who have purported that it is the manufacturers of the fertilizers who are more benefitted by the subsidies and not the farmers actually. Subsidies on chemical fertilizer are also eating into the capital that would have otherwise been used for education, research and infrastructure [7]. Even though fertilizers will remain to be one of the most important elements in the domain of agriculture aspect is related to its distribution equity, application and availability of subsidies on different crops in different states and for different classes and sizes of farmers must be taken into account.

\section{Trends in fertiliser subsidy:}

The ccea (Cabinet committee on Economic Affairs) has given an approval for subsidies on nutrient base of Rs 22,178 crore on Potassic and Phosphatic fertilizers for the present financial year.

Additionally rules were relaxed where earlier Adhaar cards were required for Pm Kissan scheme benefits in Laddakh, J\&K, Meghalaya and Assam till March 2021. This was done due to slow penetration of the Adhaar.

The farmers will also gain due to the fall in the global prices of the fertilizers. Satish Chander the director general of Fertilizers Association of India said that the global prices of the different commodities along with the fertilizers are exhibiting a downward slope. The CCEA also provided an approval for the inclusion of the ammonium phosphate within the scheme of subsidy. The government will provide urea fertilizers and also 21 grades of the $\mathrm{P} \& \mathrm{~K}$ fertilizers to the farmers at reduced rates under the subsidy scheme through the network of the importers and also the manufacturers. The manufacturer's area also on a profit making end due to the plunging price rates of gas and oil [7].

\section{India's Position in Global Fertilizer Market:}

The Indian industry of fertilizer manufacture has played a rather significant role in the course of the Indian agricultural industry. The predominant trend of use of the chemical fertilizers by the Indian farmers can be taken to be the main reason that had triggered the green revolution back in the late 1960s. In the current times Indian is known to be the second largest consumer and the third biggest producer of fertilizers across the world. The Indian fertilizer manufacturing industry is divided into three segments. Firstly there happens to be the participants who belong to the private sector, and then secondly there are the public sector manufacturing units and finally the cooperative societies. The Indian government provides heavy subsidies to the fertilizers in an attempt so that they can reach all the farmers of the country and so that Indian can continue to be self-reliant in the domain of agriculture. It is in the same direction that the prices of the fertilizers are controlled and the volume of its production is kept under a strict vigilance. 


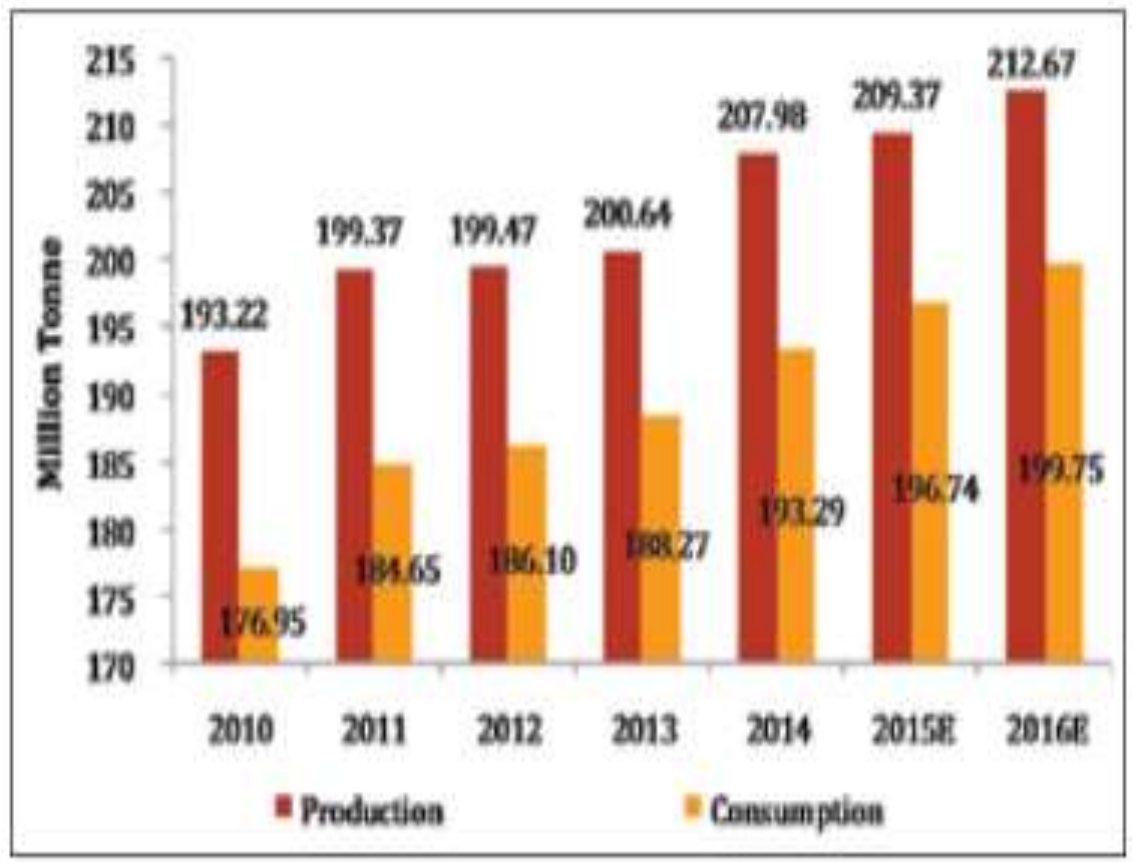

Figure 1.1:- Indian Fertilizers Production and consumption. Source: FAO Statistics and ICFA

The rate of increase I the fertilizer production in India has been at a level of $1.48 \%$ during the years $2010-14$. By the year 2016 it is expected to reach a level of 212.67 million tonnes. However even then the increase in the consumption of the fertilizer volume was rather high in Indian and was at a rate of $20.23 \%$ during the years 2010 2014. It was expected to have further increased in the coming times. This increase was due to a lack in the fertile cultivable lands and an increasing demand for food products [8].

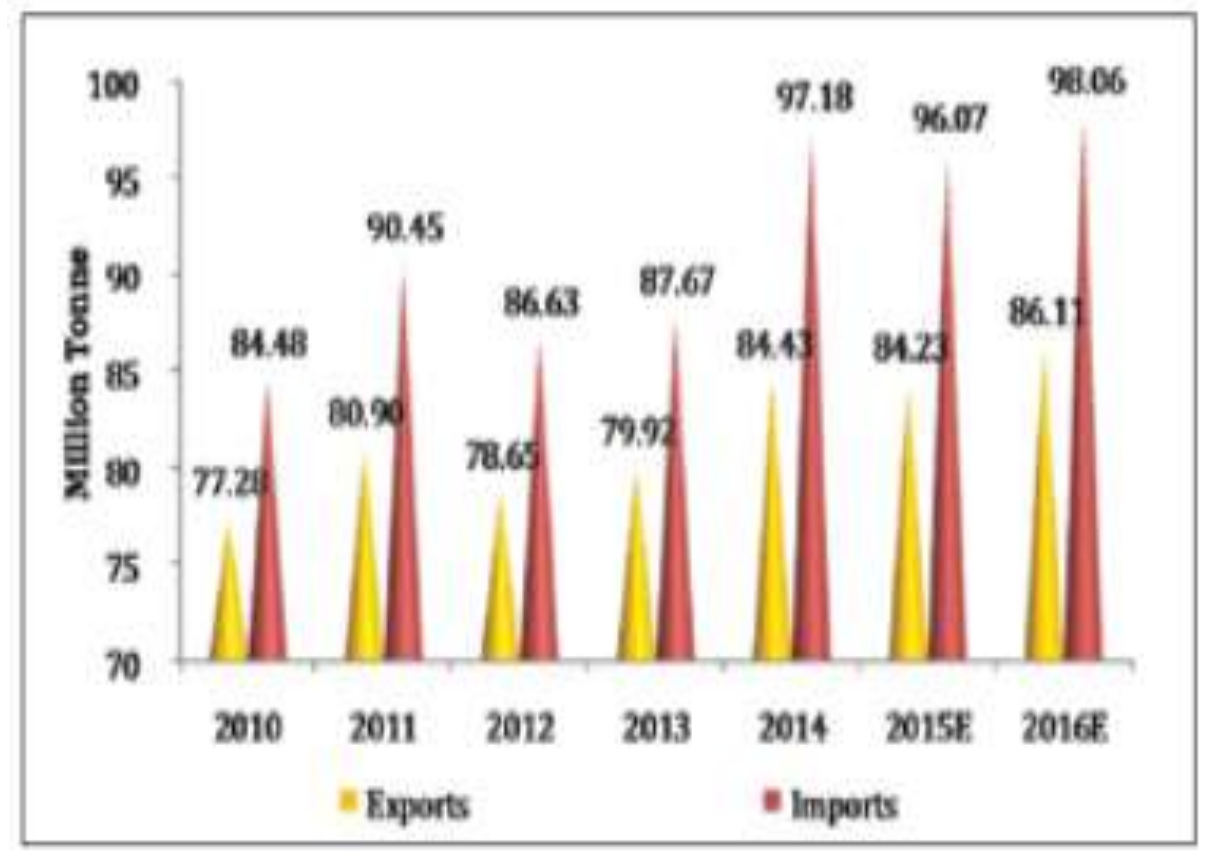

Figure 1.2: Indian Fertilizers Market trade by Volume. Source: FAO Statistics and ICFA. 


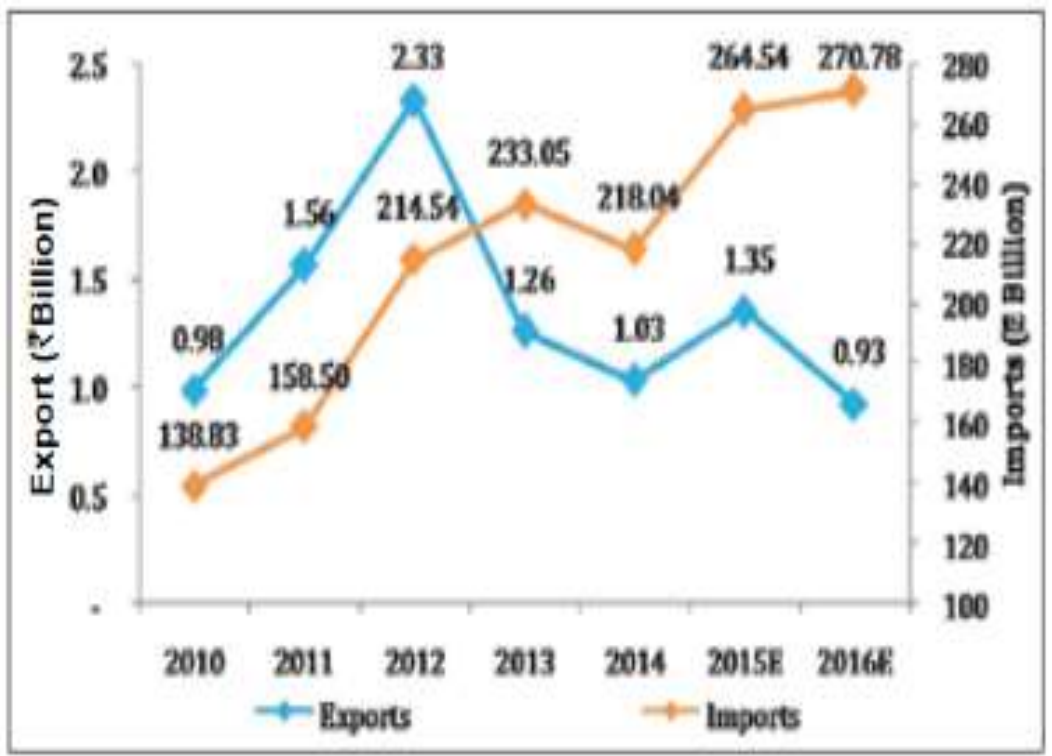

Figure 1.3:- Indian Fertilizers Market trade by Value.

Source: FAO Statistics and ICFA

\section{Indian Fertilizer Market of Trade:}

The Indian market of fertilizer is mainly dependent on foreign imports particularly the potash fertilizers. India has a shortage of the raw materials and hence it has to depend on the imports from the other countries. This leads to volatile fertilizer prices in the market. However in the current times new policies are beige made so that the prices of the raw materials can be stabilized in the future.

During the span of 2010 - 14 the volume of the Indian imports for making fertilizers did see an increase of CAGR at $2.84 \%$ but in terms of its value the import grew at a rate of $1 \%$. In the year 2012 the import volume saw a dip but the values did increase. This is a fact that could be explained by the furcating rate of foreign exchange [9].

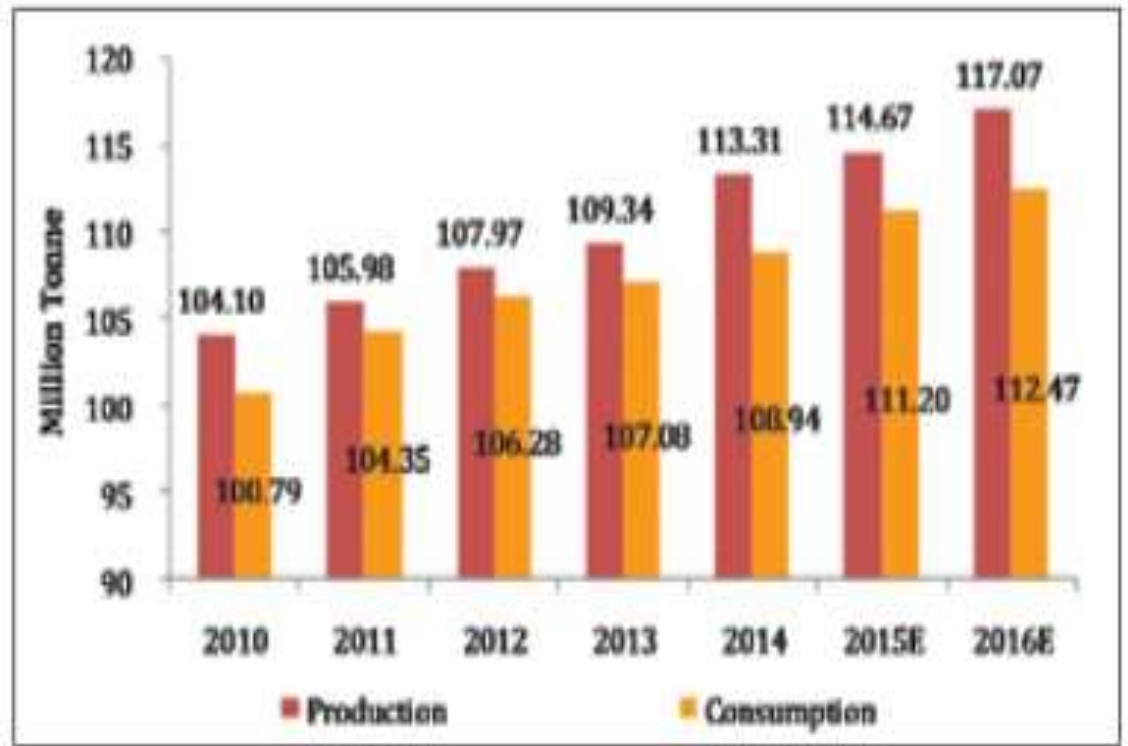

Figure 1.4:- Indian nitrogen Fertilizers Production and consumption.

Source: FAO Statistics and ICFA. 


\section{Nitrogen Fertilizer Market:}

The market for the nitrogenous fertilizers is much affected by the demand for the food grains and also the oil seeds. Manufacture of fertilizer makes use of $1.2 \%$ of the total energy of the world where nearly $90 \%$ is used for the production of ammonia, since it happens to be one of the main elements in the production of the nitrogen fertilizers. The prices of these nitrogen fertilizers is much affected by the costs of the raw materials like the prices of the crude oil, prices of the gas and other machines.

The use and the manufacture of the nitrogen fertilizers has seen a huge influx in the recent years and is anticipated to go even higher where it has shot up from 117.07 million tonnes to about 112.47 million tonnes. During the years 2010 to 2014 the production has increased at a CAGR of $1.71 \%$ where as the use shot up at an annual rate of $1.57 \%$. Urea did have the largest share in the year 2016.

The volume of trade of the nitrogen fertilizers in the past few years, however the value of the trade seems to be fluctuating as a result of the fluctuating rate of foreign exchange [10].

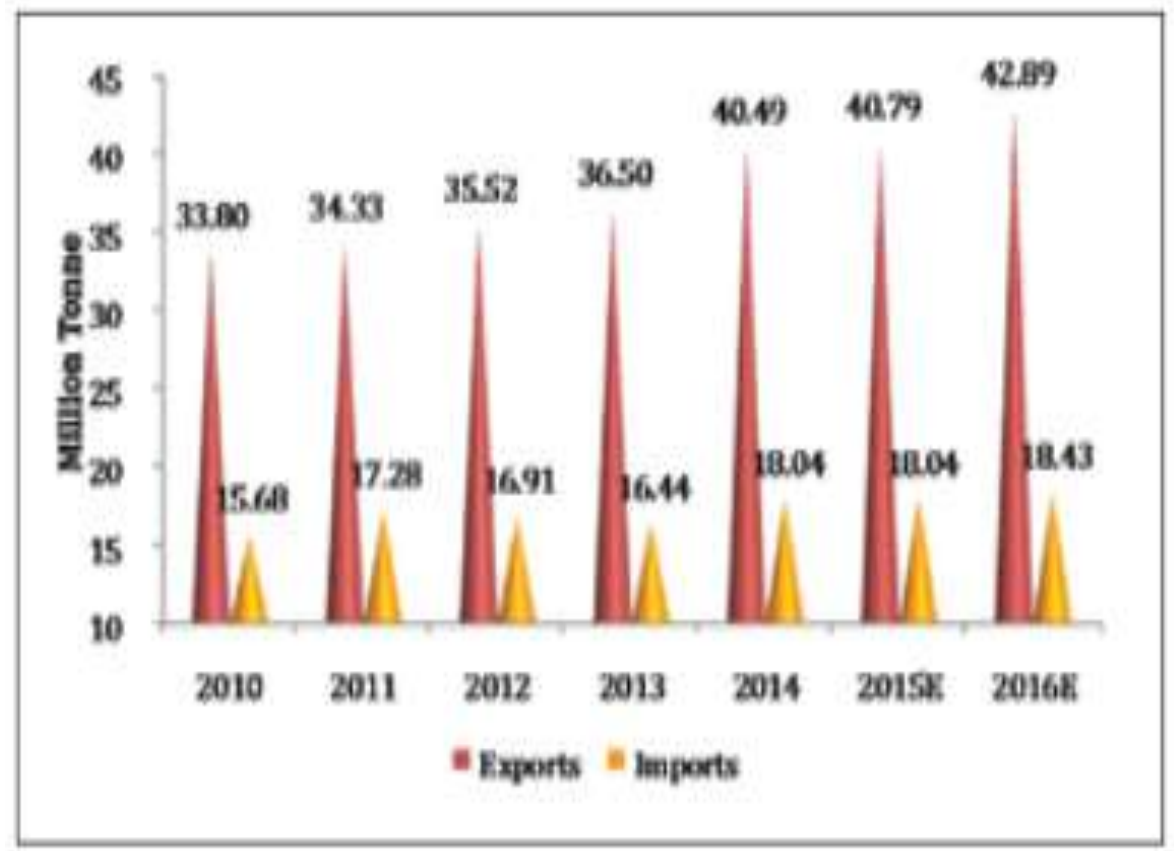

Figure 1.5:- Indian nitrogen Fertilizers trade by Volume.

Source: FAO Statistics and ICFA.

\section{Phosphate Fertilizer Market:}

The phosphate based fertilizers applications also includes the use of the phosphoric acid based chemical fertilizers along with the fertilizers that are non-phosphoric based. These non-phosphoric fertilizers will include the phosphate that is found in the nitric acid.

The demand for such fertilizers has been growing in the current times as a result of the increasing population and the growing demand for food. There is an increased demand for meat and milk which has in turn increased the demand for production of forage that can be used as feed for the cattle [11]. 


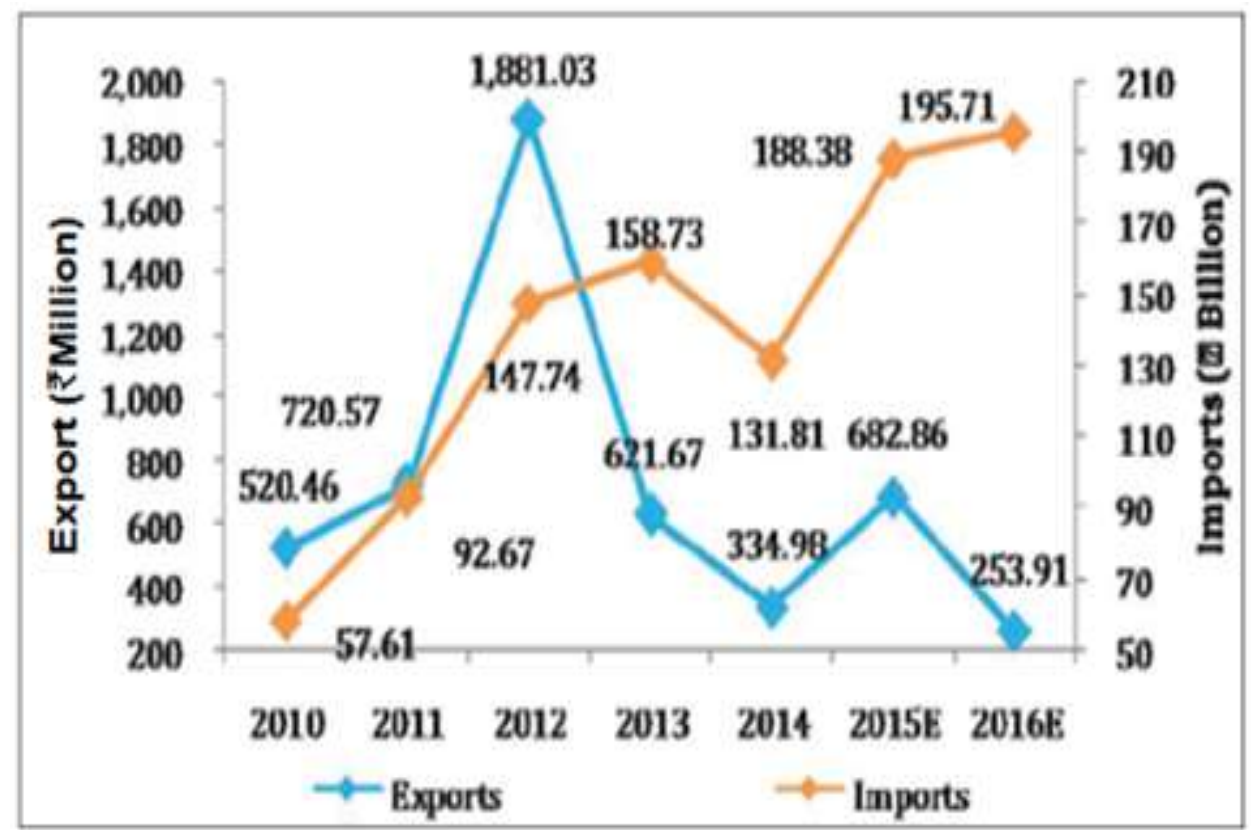

Figure 1.6:- Indian Phosphate Fertilizers Production and consumption.

Source: FAO Statistics and ICFA.

\section{Potash Fertilizer Market:}

The potash based fertilizers are commonly used for rice crops; vegetables, fruits, sugar, palm oil, soybean and also cotton due to its capacity of enhancing the crop produce, yielding a greater volume, improve the nutrient value and also make the crops more resistant to harmful parasites and various diseases. An increase in the demand of the cattle feed and also the enhanced purchasing power is factors that have contributed much to the growth of the market of potash fertilizers [12].

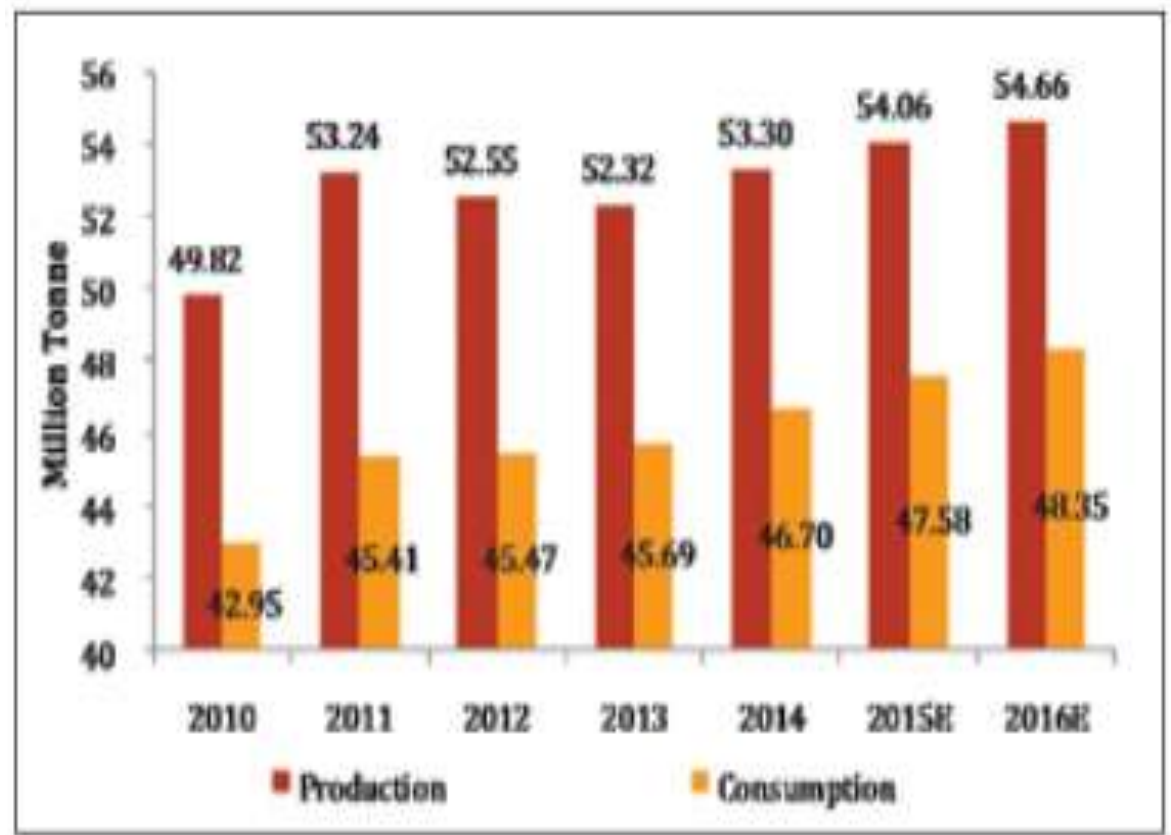

Figure 1.7:- Indian Phosphate Fertilizers Production and consumption.

Source: FAO Statistics and ICFA. 


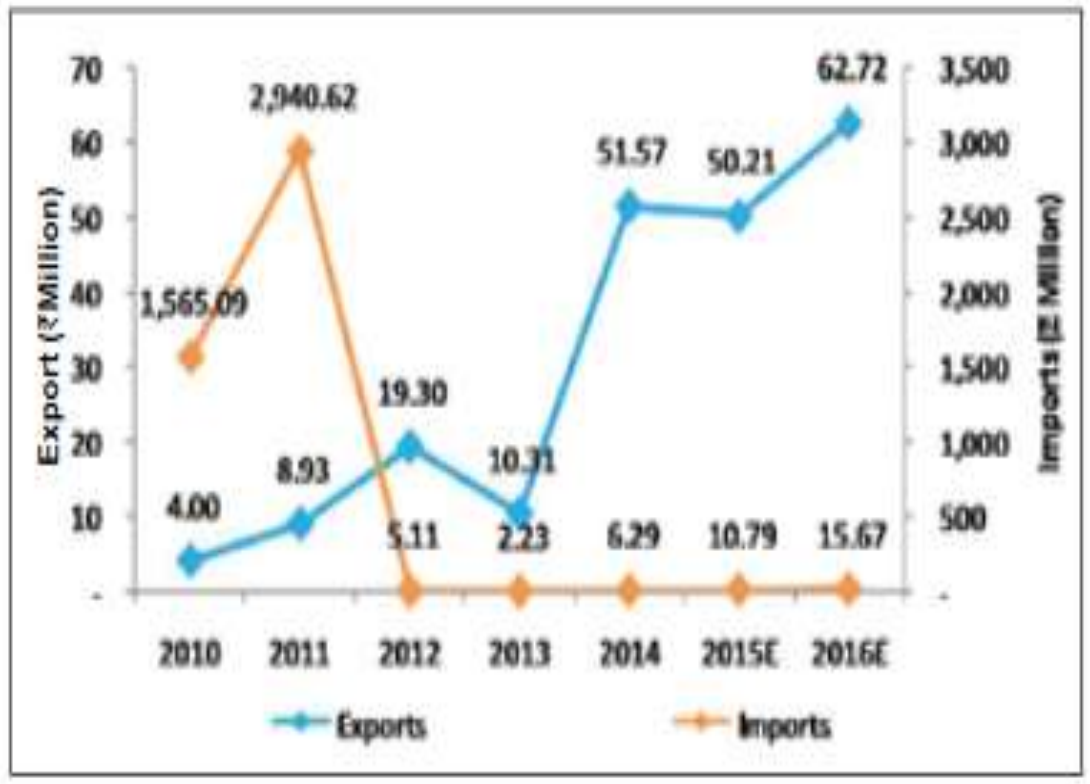

Figure 1.8:- Indian Phosphate Fertilizers trade by Value.

Source: FAO Statistics and ICFA

India has a huge demand for potash based fertilizers, of which a large portion is satiated by the imports done by India from the various other countries of the world. However in the near future India is expected to enhance its manufacture capacity of potash fertilizers owing to greater support from the government that will help bring in better quality raw materials and also modern technology of production [13].

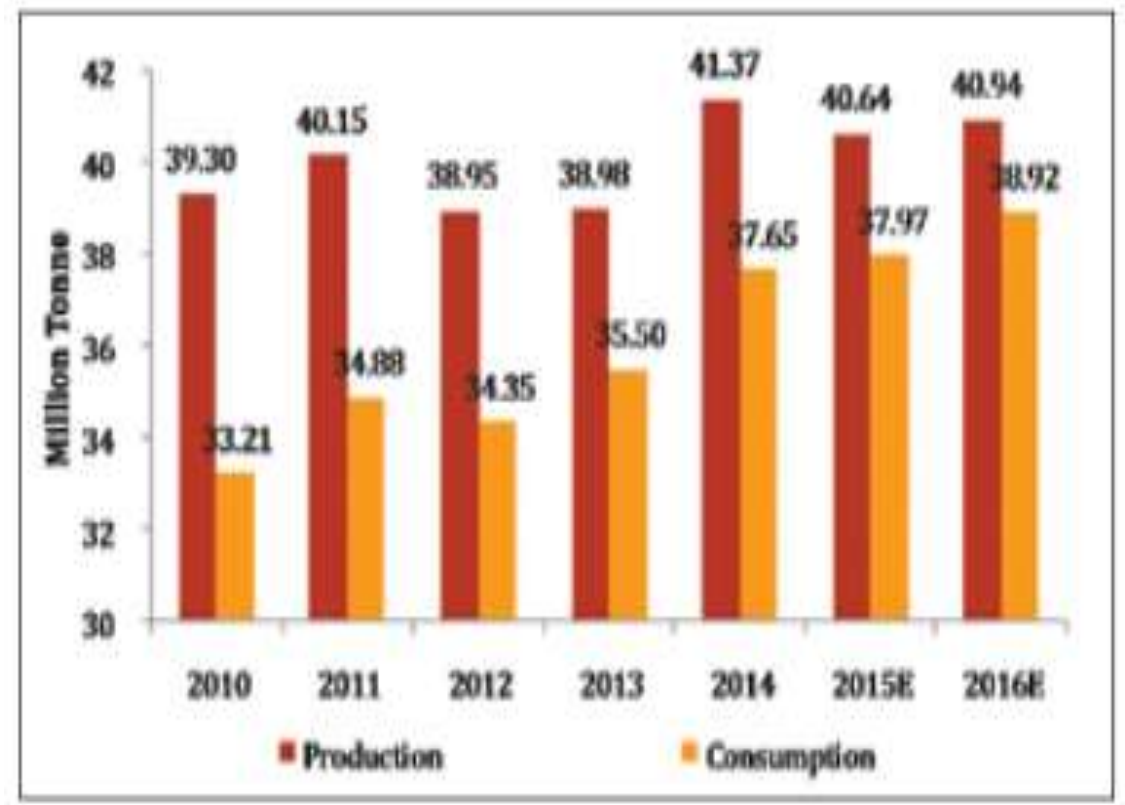

Figure 1.9:- Indian Potash Fertilizers Production and consumption.

Source: FAO Statistics and ICFA

India's Muriate of Potash (MoP) fertilizers import could reduce 5\%-7\% in the current fiscal i.e. 2017-18 due to firm global prices and cut in government subsidy. Last year, global potash prices were down, but this year it has increased slightly. 


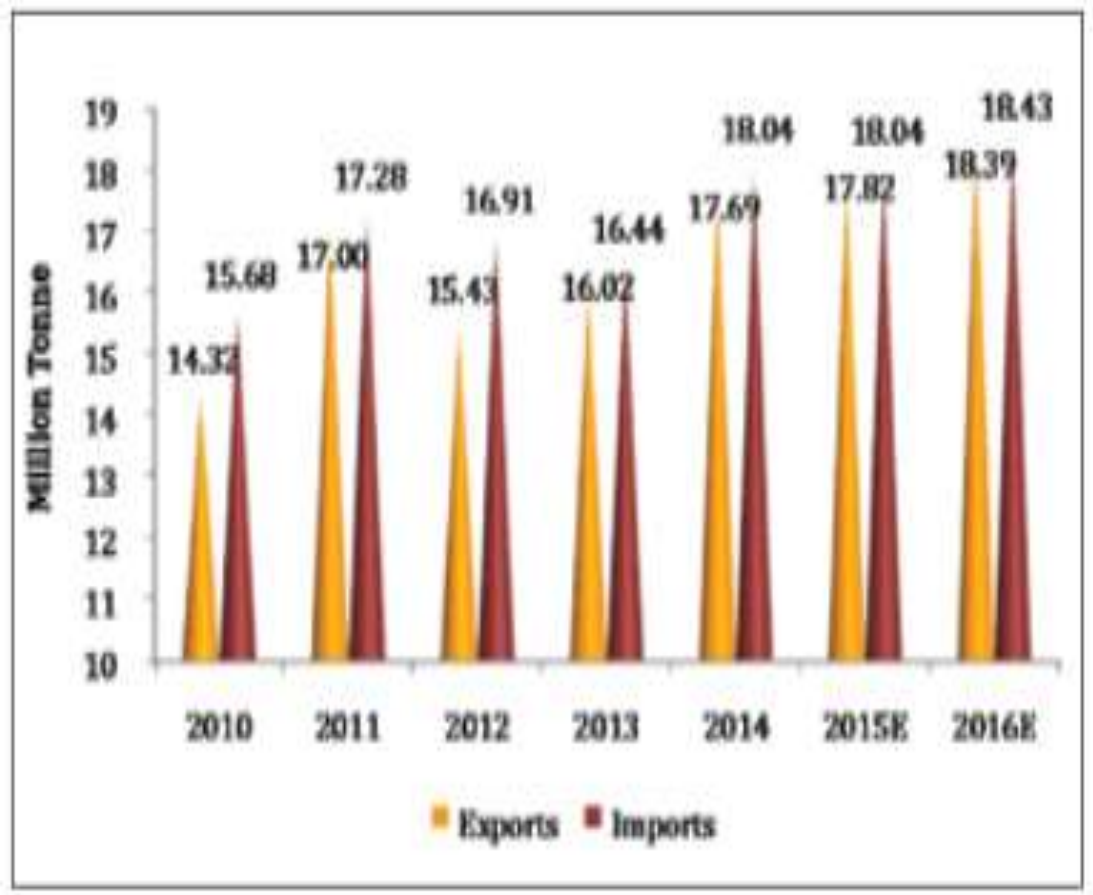

Figure 1.10:- Indian Phosphate Fertilizers trade by Volume. Source: FAO Statistics and ICFA.

The Indian agricultural industry has been much benefited by the Chemical fertilizers. It has improved and increased the overall production of crops in India. Even though India is known to be the second biggest manufacturers of nitrogenous fertilizers and the third biggest producer of phosphate fertilizers all across the world, the gap between demand and supply for fertilizers is on an increase in the Indian context. This hence has led to a greater dependency on increasing imports from different parts of the world. India has seen a wide variety of different activities in the fertilizer market. There is an enhancement in the demand of the organic or the bio fertilizers. This has happened since the excessive use of the chemical fertilizers has caused much health damage and the ground water and the ecosystems of the country have also witnessed a huge depletion [14].

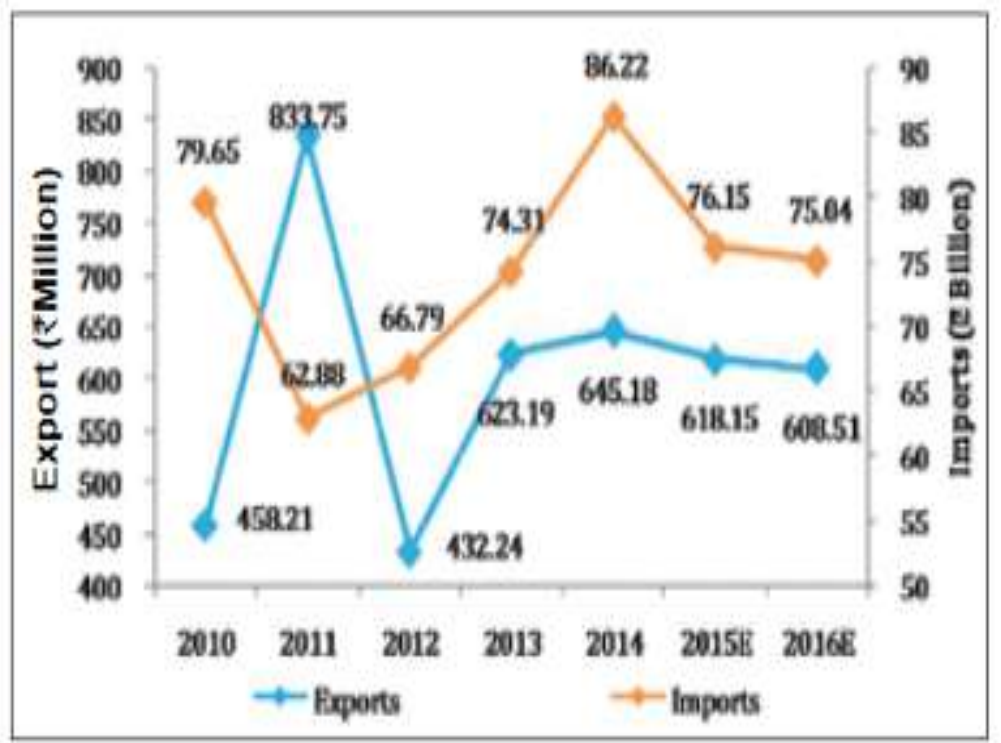

Figure 1.11:- Indian Potash Fertilizers Market trade by Value.

Source: FAO Statistics and ICFA. 


\section{Literature Review:-}

The investigations done on the domain of fertilizer subsidy in India mainly focuses on the patterns, trend, reform and impact of the industry. [15] Try to find out more of the composition of the fertilizer subsidy and have opined that a maximum part of this subsidy is mainly given to the nitrogenous fertilizer. This phenomenon brings about a massive percentage of distortion of price and also imbalance in its consumption. The paper in its discourse has proposed the requirement of reducing the fertilizer subsidy. This as a practice can improve the production of the fertilizer and can also reduce the imbalances of its use. Sharma (2012) makes an endeavor to investigate the benefits that can be enjoyed due to the present system of subsidies in fertilizers from the point of view of the farmers. It says that me marginal and the small farmers gets about $53 \%$ of the subsidy which is much higher than the area that they cultivate which comes to about $44.3 \%$ [16].

Gulati and Banerjee (2015) have conducted a comprehensive study in this field. The thesis in its course has given rise to three important issues that has a serious relevance to the present Indian fertilizer subsidy system. 1) What is the fiscal sustainability in the program of enhancing budgetary allocations in the contexts of the subsidies for the fertilizers; 2) The distortions of price that has led to lack of balance and 3) Increase in the import dependency and also the payment delays to the industry [17].

The current paper has proposed the alternative policy options: (a) A switch must be made to transfer of direct cash to the accounts of the farmers on the basis of per ha, the prices of urea must be determined by the forces of demand and supply in the open markets (b) the programs of soil health must be taken seriously, in this context the [18] farmers must be communicated to in a clear manner and if required cash help must also be given to them; (c) The Indian firms must invest in the nitrogenous fertilizer companies in the Gulf where the prices are less than US\$3 per million British thermal units (MMBTU) as compared to the pooled price of \$10.5 per MMBTU in India. As per [19], some investigations this is a step that can promote efficiency in the production and consumption and also offer a stable policy to the sector of fertilizer to ensure sustainable and efficient growth [20].

The program of subsidy for fertilizer in India has been a part of the program of Green revolution that took place in the late 1960s. The main aim of the program was to increase the agricultural output of the nation by providing the inputs of farming to the farmers at an affordable price. The subsidies encouraged the use of fertilizers that not just increased their importance in the domain of Indian agriculture but at the same time also increased the output of the nation [21]. However its contribution in the context of the national agricultural industry and reducing the poverty of the farmers has decreased steadily over the recent past.

\section{Conclusion:-}

This research paper reveals that the domestic production of fertilizers has not increased keeping the track with the rapid increase in the consumption of fertilizers in the country. So, India is depending on the imports of fertilizers and fertilizer feedstocks to mitigate the gap between demand and supply. Moreover, it is detected in this research paper that the import prices of feedstocks like ammonia, phosphoric acid, and sulphur have increased quite a bit but the respective gate prices have not been revised accordingly. It leads to higher amounts of subsidy. Therefore, this research paper suggests that in order to accomplish fiscal consolidation, the Central Government should remodel the subsidy. The control over the price of Urea can be withdrawn and left to the market force. Newest technologies can be used to track small farmers with limited investment whom subsidy can be given leaving capable farmers or owners of large lands. Digitalization of land records can be helpful in many ways. Benefits can be transferred directly to the small and needy farmers like DBT scheme for LPG.

\section{References:-}

1. Rao, S. A. and Reddy, S.A. (2015). Emergingstrategies for sustaining higher productivity andensuring soil quality under intensiveagriculture. Indian J. Fert., 1 (4), 61-76

2. Walkley, A. and Black, I. A. (2014). An examination ofDegtjareff method for determining soil organicmatter and proposed modification of the chromic acid titration method. Soil Sci. 37, 29-38

3. Chand, R. and Pandey,L. M. (2018). Fertiliser Growth, Imbalances and Subsidies: Trends and Implications, National Professor Project Discussion Paper 02/2008. Retrieved from: http://sa.indiaenvironmentportal.org.in/files/fertiliser.pdf

4. Department of Fertilisers. (2014). Annual Report 2013-14, Government of India, New Delhi 
5. Government of India. (2013.) Report of the Working Group on the Fertiliser Industry for the Twelfth Plan (2012-13 to 2016-17), Department of Fertilisers, Ministry of Chemicals and Fertilisers, New Delhi, India

6. Gulati, A. and Banarjee, P. (2015). Rationalising Fertiliser Subsidy in India: Key Issues and Policy Options, retrieved from http://icrier.org/pdf/Working_Paper_307.pdf http://www.moneycontrol.com

7. Kelkar Committee Report. (2012). Report of the Committee on Roadmap for Fiscal Consolidation, Ministry of Finance, New Delhi, India

8. Morris, M. Kelly, V. A. Kopicki, R. and Byerlee, D. (2017). Promoting Increased Fertiliser Use in Africa: Lessons Learned and Good Practice Guidelines, World Bank, Washington, DC.

9. PMEAC. (2012). Economic Outlook 2012/13, Economic Advisory Council to the Prime Minister, New Delhi.

10. Sector Growth, working paper No. 2012-09-01 retrieved from:

11. http://www.iimahd.ernet.in/assets/snippets/workingpaperpdf/14668129402012-09-01.pdfSharma, V. P. (2012). Dismantling Fertiliser Subsidies in India: Some Issues and Concerns for Farm Sector Growth, working paper No. 2012-09-01 retrieved from: http://www.iimahd.ernet.in/assets/snippets/workingpaperpdf/1466812940201209-01.pdf

12. Srivastava, D. K. Bhujanga Rao, C. Chakraborty, P. and Rangamannar, T. S. (2003). Budgetary Subsidies in India: Subsidising Social and Economic Services, National Institute of Public Finance and Policy for Planning Commission, Government of India. Retrieved from: http://planningcommission.nic.in/reports/sereport/ser/stdy_bgdsubs.pdf

13. Chand, R. (2015). 'Subsidy Structure Too Complex for Knee-Jerk Response', Farmers' Forum. 14(6).

14. Chopra, R. N. (2012). Evolution of Food Policy in India, Macmillan India Limited, New Delhi, India

15. Ernst and Young (2014). Study on the Nutrient Based Subsidy policy for P\&K Fertilizers, Oct 2014

16. Sharma, V. P. (2012). Dismantling Fertiliser Subsidies in India: Some Issues and Concerns forFarm

17. Gulati, A. and Sharma, A. N. (2012). 'Subsidising Agriculture-a Cross Country View', Economic and Political Weekly. 39.

18. Huang, J. and Xiang, C. (2015). 'Fertiliser Subsidies in China: Which Way Forward?' International Food and Agricultural Trade Policy Council Discussion Paper, forthcoming

19. Kumar, R. Devkumar, C. Kumar, R. and Gupta, A. K. (2012). 'A Simple and Robust Method for Determination of Neem (Azadirachta indica A. Juss) Oil in Neem Oil Coated Urea' Toxicological and Environmental Chemistry. 4.

20. SEWA Bharat (2012). An Experimental Pilot Cash Transfer Study in Delhi, An Initiative under GNCTDUNDP Project, Government of Delhi, Retrieved http://www.undp.org/content/dam/india/docs/poverty/Final-study-results-SEWA-PDS.pdf on 29.04.2015

21. United Nations (2014). The World Population Situation in 2014: A concise Report, Department of Economic and Social Affairs, Population Division, New York. 